UDC 378.018.43:159.98-054.6-057.875(73)

DOI: $10.52534 / \mathrm{msu}-$ pp.7(3).2021.18-28

Yaroslav S. Slutskiy ${ }^{1 *}$, Colin Blanchard ${ }^{2}$

${ }^{1}$ Donbas State College of Technology and Management

85200, 3A Yevhen Sedniev Str., Toretsk, Ukraine

${ }^{2}$ Indiana State University

IN 47809, 200 North Seventh Str., Terre Haute, United States

\title{
Programmes for Remote Counselling of International Students in the Higher Education Institutions of the United States of America
}

\section{Article's History: \\ Received: 15.05.2021 \\ Revised: 28.06.2021 \\ Accepted: 05.08.2021}

\section{Suggested Citation:}

Slutskiy, Ya.S., \& Blanchard, C. (2021).

Programmes for remote counselling of international students in the higher education institutions of the United States of America. Scientific Bulletin of Mukachevo State University. Series "Pedagogy and Psychology", 7(3), 18-28.
Abstract. The relevance of the study lies in the necessity of developing the remote forms of counselling work with foreign students during the adaptation period. In this regard, the purpose of the present study is to analyse the programmes of remote counselling of international students at HEIs in the US to determine the potential for extrapolation of foreign experience into the higher education systems of other countries. We applied a number of methods, such as analysis, synthesis, abstraction, the method of moving from abstract to concrete, which enable a comprehensive review of the issue of remote counselling of international students. The article studies the aspects of online counselling of international students. Psychological support has been observed to be an element of the acculturation triad and therefore should be considered in the context of the education process. The article emphasises that since international students are exposed to the negative influence of the phenomenon of "culture shock", and they should participate in relevant initiatives aimed at the development of skills for overcoming emotional and psychological issues. We have analysed the programmes, courses, and seminars of the University of Minnesota and the Florida International University, which allowed determining the algorithm for the development of the online counselling system, namely providing international students with informational reference materials (including reading materials and videos) for their personal guidance and general understanding of the challenges relevant for foreign students; holding personal meetings between a student and a counsellor via video conferences, which allows discussing the existing psychological issues and build interpersonal relationships. The practical benefits of this study reside in the fact that the development of remote programmes, courses and seminars (with the introduction of foreign experience to such activities) will have a positive impact on the psychological support system at the country level and will facilitate further development of remote education systems and ensure the increased use of modern ICTs in education and other areas

Keywords: culture shock, negative psychological acculturation system, informational reference material, psychological support platform

\section{INTRODUCTION}

International students in the education system of a country are an indicator of the level of quality and efficiency of services provided by this system. Continuous development allows ensuring the adequate degree of flexibility of educational institutions, which has a direct impact on two major aspects related to international students, namely:
- enrolment of students from developed countries at educational institutions will allow ensuring a higher level of educational international cooperation, which will facilitate further development of the national education system of a given country;

- availability of modern means for the "preparation" for 
academia in addition to educational purposes will allow attracting a number of international students, which will improve the financial component of the education system of a country.

According to the data provided by the Ukrainian State Centre for International Education (USCIE), 80,470 students from 158 countries were attending higher education institutions in Ukraine as at 1 January 2020 [1]. At first glance, these statistics show the diversity of the student body. However, the data provided by the USCIE reveals that the majority of international students studying in Ukraine are from countries such as India, Morocco, Azerbaijan, Turkmenistan, Nigeria, Turkey, China etc., which shows the lack of attractiveness of Ukrainian HEI for students from the EU countries [1]. Therefore, it is necessary to improve the education system (in Ukraine in particular) in certain areas. We believe that reaching this goal requires a more active introduction of new education elements, which can help to enhance the competitiveness of HEIs. Such modernisation measures may include international best practices, which should be applied at universities and professional pre-higher education institutions with a certain level of adaptation.

Taking into account that educational institutions in the United States are attended by the largest number of international students in comparison with other countries, it would be reasonable to examine their approaches that can be adopted by HEIs in other countries. First of all, the development of systems for remote interaction between a teacher and a foreign student can be considered a promising initiative. The development of this approach, in particular at Ukrainian HEIs, has been incentivised by the COVID-19 pandemic. However, most often remote programmes are introduced by educational institutions for teaching purposes, resulting in the increased use of remote learning platforms (Moodle, Google Classroom, Prometheus, EdEra, etc.), online classes (the All-Ukrainian Online School), as well as video conferences (Hangouts, ZOOM, Skype, Google Meet, Microsoft Teams). Still, when considering the remote academic practices of American HEIs, it is worth noting remote programmes for psychological support of international students.

Remote means of providing psychological supports are most effective if educational institutions have introduced distance learning and an international student cannot participate in face-to-face counselling. Drawing on the conclusion that the aim of counselling is "to provide psychological support, i.e., a conversation with a counsellor should help a person deal with their issues and establish interpersonal relationships with others" [2, p. 17], we should also note that counselling is essential for successful adaptation process of a foreign student. However, the most common types of psychological counselling are qualitatively different in terms of working with international students; for example, correspondence or telephone communication is not enough because counselees have a different cultural background, so it is necessary to use both verbal and non-verbal means of communication, and a direct face-to-face interaction between a counsellor and a student is required.
According to the findings of $\mathrm{H}$. Widodo, S. Ferdiansyah \& L. Fridani [3, p. 9], in the context of quarantine measures, psychological well-being is one of the conceptual aspects for an international student; moreover, "students should prepare themselves ... psychologically". Therefore, psychological issues are relevant even in the remote learning environment. If psychological support is ignored, it can adversely affect the academic process of an international student over time, due to their inner psychological issues rather than underperformance caused by an intellectual inability to digest information.

Notably, counselling is inadequately developed in Ukrainian HEIs even in a face-to-face format. Speaking about this kind of support of international students (and comparing it with the experience of the US in implementing remote counselling), this practice can be singled out as a promising one in terms of active implementation and development.

Moreover, academic activities of international students (as well as Ukrainian ones) in the context of remote learning and its inherent challenges related to the difficulties of establishing direct contact with the teacher and the team have negative psychological consequences. While in the times of standard learning such students had access to psychological support (at the educational institutions where its provision was well developed), after switching to remote learning (which does not reduce but in fact increases the impact of psychological issues (e.g., culture shock) on the student), getting counsellor's support face-to-face has become difficult or sometimes even impossible.

Thus, overcoming these negative factors can be considered one of the main tasks of counselling activities, which have been reviewed in the study of J. Hua, G. Zhang, \& Ch. Coco [4] allowing the researchers to identify the need for combining different elements of the adaptation process (such as social learning and the usage of cross-cultural literature) to create the conditions for foreign students to develop a psychological superstructure, thereby ensuring individual resilience in the context of interpersonal interaction in a new society.

As mentioned above, the main psychological issue that negatively affects academic activities of international students is culture shock, which results in the inconsistency of social and cultural views of people from different countries. Thus, C. Ward, S. Bochner, \& A. Furnham [5] examined the nature of culture shock, which is the main reason for the emergence of psychological issues among international students. However, these studies have not paid due attention to the usage of the remote format for overcoming the issues they considered.

Therefore, we consider it necessary to examine the experience of American HEIs in implementing remote psychological support programmes and techniques to develop such approaches at educational institutions in other countries, which will allow both ensuring more effective preparation of HEIs for remote education (since, when it comes to international students, education is not only about teaching 
a subject; linguistic, cultural and psychological training play a critical role) but also to improve quality of their education following the international best practices.

This relevance allows defining the objective of the article: to analyse the programmes of remote counselling of international students at HEIs in the US to determine the potential for extrapolation of foreign experience into the higher education systems of other countries.

\section{LITERATURE REVIEW}

Psychological support of an international student is essential in their adaptation to a new environment. Therefore, apart from language training and teaching on principles of cultural diversity, the interaction between an international student and a new academic and cultural space should include effective psychological support, so that the student experiences acculturation in calmer emotional and psychological environment.

The development of modern communication means allowing remote interaction with other people online and their increasing implementation in all areas of society raises the issue of the necessity of the use of these innovations in various fields and education in particular. Notably, the effectiveness of an educational institution in present-day world depends on its ability to provide all possible kinds of activities in a flexible format, which can mitigate negative consequences of any aspect of the external environment. The COVID-19 pandemic can be considered the most influential factor that has recently highlighted the need for capacity and expertise to ensure the education process at the highest possible quality level, because quarantine measures and remote learning that have been introduced in numerous educational institutions and countries have not eliminated the need for education for both traditional (local) and international students, who have not stopped learning after the announcement of the pandemic and the introduction of quarantine restrictions. However, the issues of such students have not become "remote" or "distanced"; they keep leading to negative consequences, thus calling for appropriate adaptive measures.

First of all, let us consider the definitions used in this study, i.e., the terms "counsellor", "counselling", and "psychological counselling". For example, the Great Explanatory Dictionary of Modern Ukrainian Language defines the word "counsellor" as "a specialist whose official duty is to provide advice and conclusions on matters related to their speciality" [6, p. 567]. Therefore, if someone provides an international student with psychological advice and support (for example, in universities and colleges in the US, a student can receive counselling at their educational institution or a counselling centre operating under the HEI, or at the International Student Aid Office), such a person can be called a counsellor. The Dictionary of the Ukrainian Language, in turn, specifies that 'to counsel' means "to advise on any matter" [7, p. 267]. It means that if a counsellor gives practical advice working directly with a student (one-on-one format) or a group of students (group format), or using remote means of counselling (via phone, video conference, or by correspondence), this activity can be called counselling. The definition provided by the Complete Guide to Social Work encyclopaedic dictionary specifies that counselling is an interaction between two or more people where the specialised knowledge of the counsellor is used to provide help to the counselee in resolving issues or in creating an algorithm for personal development [8, p. 219]. Therefore, in terms of the remote counselling, this definition suggests that it has at least two participants who establish the link "counsellor - counselee". If there are more persons involved in counselling, it can lead to the establishment of the links "counsellor - counselees", "counselee - counselee", "counselee - counselees". Therefore, remote counselling can be considered full-scale psychological support provided in accordance with the above characterises.

The importance of counselling is also evidenced by the findings showing that the adaptive capacity of a foreign student has the following three basic elements: "physiological adaptability, psychological adaptability, and social adaptability" [9, p. 117]. Thus, insufficient functioning of any of these elements leads to the adaptation sequence problems.

We can conclude that modern ICTs should be used for the psychological support of international students. At the same time, online counselling can be considered the only available form of counselling in the context of quarantine restrictions. As for Ukrainian HEIs, most of them have an on-staff psychologist, although this cannot be considered the evidence of the systematic and structured provision of psychological support. However, the need for remote working poses the question as to whether a HEI can provide international students with full-scale psychological support, given that online counselling "allows using virtually unlimited resources for the implementation of various forms of interaction between the interested participants while they identify, discuss and practically solve various questions and issues" [10, p. 14]. In contrast to the standard learning process, which has been covered to a certain extent, and where practices of the use of various platforms of remote learning are being implemented, the issue of the provision of psychological support to international students has not been adequately addressed and discussed by public and in academia, which, of course, does not mean that problems related to the adaptation issues do not exist and cannot become more severe.

At first glance, it may seem that remote counselling lacks the appropriate level of efficiency due to the absence of direct interaction between the counsellor and counselee, but this is refuted by the findings of V. Mytsko [11, p. 73], highlighting that "the substantive feature of online counselling is its accessibility". The issue of accessibility and efficiency of remote counselling has also been addressed by Yu. Akymenko [12, p. 44-45]. Therefore, drawing on the claims of researchers, it can be said that there is a theoretical possibility of the provision of psychological support to international students in the context of quarantine restrictions. 
In general, when addressing the remote counselling of international students, it should be highlighted that the research base is limited and that the main area of research is the study of psychological issues relating to remote learning (S. Postek, M. Ledzińska, \& J. Czarkowski [13]); an overview of MOOCs online courses (M. Baturau [14]; S. Pouezevara [15]). As for studies conducted in the US, the analyses of the types of online learning (H. Kentnor [16]); as well as of the significance of online learning for the effectiveness of educational process (M. Bakia, L. Shear, Y. Toyama, \& A. Lasseter [17]) are the most relevant. We would also like to highlight the statistical surveys (J. Seaman, E. Allen, \& J. Seaman [18]) dealing with remote learning in the US (including the level of involvement of higher education institutions and students representing different courses and fields of study into this type of provision of educational services). However, it should be noted that the above studies have been of a comparative (examining traditional and remote education to reveal pros and cons of each) or statistical and reference nature (examining the development or stagnation of remote learning). In conclusion, there has not been any thorough research on remote counselling programmes for international students.

Therefore, for our study, the most concrete study results should be examined. In this case, the conclusions made by J. Hunt \& D. Eisenberg [19] concerning overcoming of psychological issues by college students can be considered useful; while H. Forbes-Mewett \& A.-M. Sawyer [20], in particular, focused on the nature of psychological issues of international students, which is necessary for the creation and development of methods for overcoming them.

As for studies of remote counselling conducted by Ukrainian researchers, we would like to highlight the studies dealing with the counselling models and methods that use the Internet (N. Afanasieva [10]); the review of special features, advantages and disadvantages of remote counselling (V. Mytsko [11]); the feasibility of implementing remote counselling in comparison with traditional psychological support means (Yu. Akymenko [12]). However, despite the existence of the studies on the role of remote counselling in the Ukrainian academia, it is still necessary to address the issue of the provision of psychological support to international students.

However, as noted above, the psychological component of the remote educational system has been not adequately addressed. It is therefore necessary to examine the practical experience of the usage of remote programmes of the psychological support of international students in the global context, and the University of Minnesota and the Florida International University of the US have been selected for this purpose. In addition, these educational institutions offer counselling programmes for international students.

\section{MATERIALS AND METHODS}

To reach the objective of this study, we applied a number of methods to conduct a comprehensive review of the issue of remote counselling of international students. The methodology of the article includes the following elements:

- analysis (psychologically oriented programmes include sub-programmes, so it was necessary to identify the features of those sub-programmes within the scope of the study, and the method of analysis was used for that purpose, which allowed differentiating counselling sub-programmes from the general programmes and thus determining an adaptation strategy for international students. The method of analysis was also used to define the basic conceptual framework derived from "counselling". In addition, the application of the analysis allowed constructing a "negative psychological acculturation system" due to the fact that the identification of the root causes of psychological problems is possible with a detailed separation of the symptoms that appear in the personality. Accordingly, the construction of this system is possible as a result of analytical actions called to identify the root causes of the problem);

- synthesis (in turn, differentiating efforts taken required restoring the integrity of the remote counselling system to draw conclusions and determine the prospects for further scientific studies. As a consequence, the synthesis method allowed grouping sub-programmes into programmes and programmes into the counselling system of a given educational institution);

- abstraction (since the concept of counselling includes many aspects, the method of abstraction was used to narrow the field of study, which was eventually defined as remote physiological counselling of international students at HEIs in the US. In addition, this method was used to investigate the psychological counselling of international students. Notably, the process of adaptation of international students has three major components, namely linguistic, cultural, and psychological. While linguistic and cultural training can be in the format of online lectures or tasks with the use of various platforms (Coursera, edX, or local university platforms), there is an issue of the means for psychological support in the context of the remote provision of educational services. It was in this case that abstraction was used, which allowed directing the study towards the remote psychological counselling as one of the elements of international students' adaptive training, without touching upon issues of linguistic or cultural training);

- the method of moving from abstract to concrete (at the initial stage, the study of the specified issue required an abstract review of the main principles of counselling and adaptation training of international students in general. At the second stage of the application of this method, we specified the essential aspects of the remote counselling programmes and sub-programmes, thus leaving aside the abstract understanding of the issues and focusing on the multifaceted nature of the system under study);

- the method of deduction and induction (the deductive approach in our study allowed to identify the components of the "negative psychological acculturation system". A general understanding of the essence of psychological counselling to solve certain personal issues that negatively 
influence on the international students' interpersonal interaction with representatives of the host country. It allowed distinguishing between the stages of the acculturation system, given that these stages are not independent units but the constructs of a subsequent stages, which, as a result, form this system. As for the method of induction, it was used to combine these stages into a single acculturation system and a system of international students' psychological support of a particular educational institution).

\section{RESULTS AND DISCUSSION}

\section{Practices of remote counselling of international students at the University of Minnesota}

First of all, let us consider the approaches to remote counselling of international students used at the University of Minnesota, where students have an access to counselling services (Student Counselling Services), with the main one being Online Counselling [21], which helps international students develop skills of dealing with social anxiety and depression symptoms or stressful situations. Sessions consist of viewing informational videos, theory on the skills that would help overcome negative psychological and emotional responses such as depression, stress, etc.; students can also get online support and feedback from the specialists. The key advantage of the Online Counselling programme is that it allows taking part in the sessions through the use of modern technologies, so the sessions can be held anytime and anywhere, thus making the provision of psychological support more flexible.

In this respect, two main aspects can be identified. materials and means for receiving the counselee's feedback, in particular for discussing the materials the student has watched. In other words, prior to counselling, a student is provided with the theoretical basis to build a counselling session via video conferencing. The second aspect is overcoming symptoms of depression and stress through online counselling by searching for the root causes of psychological issues. For example, it can be a system that we will call "the negative psychological acculturation system". Essentially, culture shock as well as stressful situations related to the necessity to act differently increases the risk of feeling that one's expectations have not fully become reality. Accumulating such feelings eventually results in an inner fear of possible failures, which negatively affects the process of adaptation, because in this case, students are uncertain in the correctness of certain actions. This results in an inadequate adaptation training, which leads to the response that can be represented by the following formula: the anxiety about the result caused by negative experiences - the inability to perform adaptation tasks - the insufficient level of preparation to acculturation - academic and socio-cultural issues and difficulties - the anxiety about the results caused by having negative experience (Fig. 1). Thus, it is vital to understand that this system of psychological imbalance of an individual is also relevant in the context of remote learning, pointing to the need for remote counselling to break links of the system. Therefore, we believe that practices of theoretical informing of international students about possible psychological adaptation issues, as well as the use of modern means for communication between a counsellor and a counselee are a positive development.

The first one is the importance of using informational video

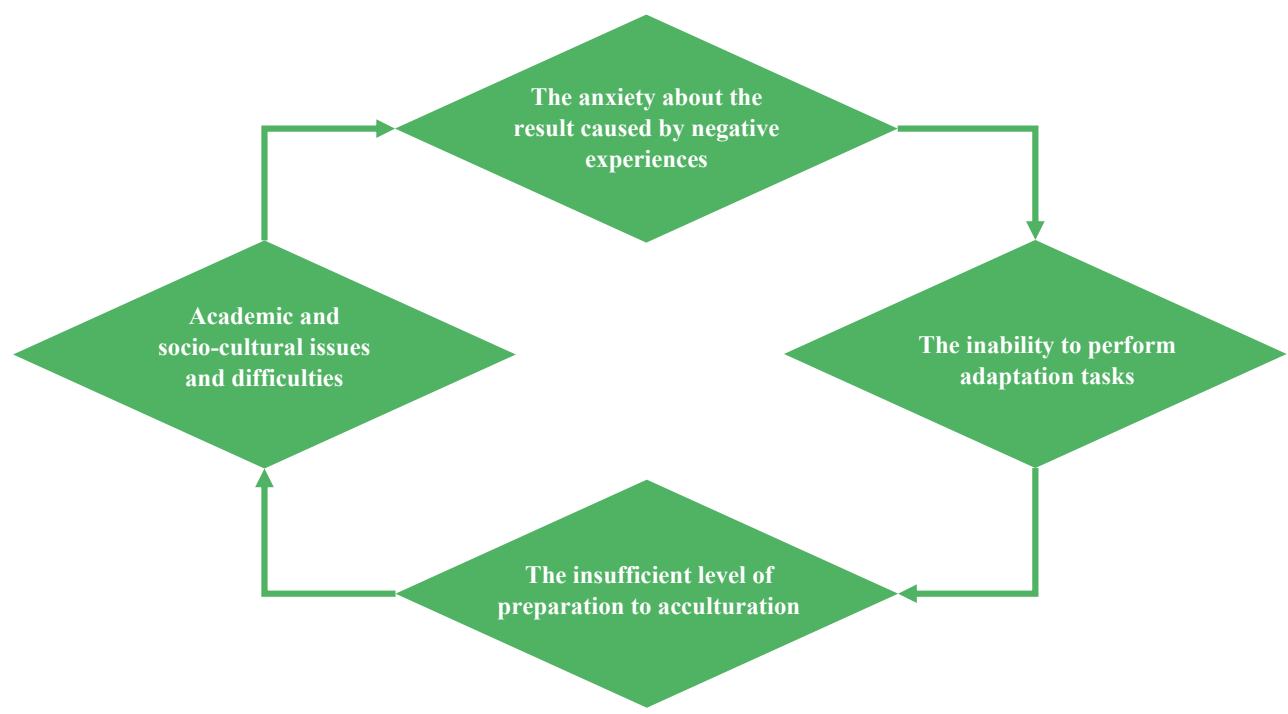

Figure 1. Negative psychological acculturation system

Examination of the remote counselling system of the University of Minnesota has revealed that the initiatives (known as the Student Counselling Services) are aimed at the work of the Online Counselling programme, the main goal of which is overcoming the negative emotional and psychological impact of culture shock, such as depressive disorders, social anxiety or the presence of persistent stressful situations. The programme aims to provide international students with information, which helps them understand aspects and causes of their psychological issues using 
theoretical videos and reading materials that are provided remotely. In addition, having developed a certain theoretical background, international students can also take part in sessions held by a counsellor via video conferencing, which contributes to a more effective analysis of certain personal issues (in comparison with self-analysis that could be conducted by students without any help). In conclusion, the combination of psychological self-learning and direct counselling is aimed at destroying the foundations of the "negative psychological acculturation system" resulting from culture shock and leading, among other things, to depression, inability to make their own decisions based on personal views (conformity) etc.

\section{Psychological support of international students at the Florida International University}

At the same time, practices of the Florida International University can serve as an example of the vigorous implementation of remote counselling programmes into the process of the adaptation work with international students. We consider it necessary to provide a more detailed review of the experience of this educational institution, which is represented by the Online Self-Help programme [22], that is strongly supported by the FIU Counselling and Psychological Services and provides international students with resources for maintaining their psychological health, as well as for developing emotional resilience via the use of the online environment. A special feature of this programme is the provision of resources (via remote counselling only), which are identical to those that are used by students during face-to-face counselling sessions. The online psychological support resource base of the Florida International University includes The TAO Therapy [23;24], which has been described as an online platform containing educational content aimed at understanding one's own mind and emotions. Apart from awareness-raising materials available at the platform, students can hold weekly online meetings with a counsellor in the format of a brief video conference, which facilitates getting proper support and advice on the matters related to overcoming of current issues. The goal of therapy is to help international students understand the nature of certain issues of a specific individual and develop skills, which will become the tools that can be used to overcome the existing and future stressful situations. Therefore, the TAO Therapy ensures that international students are fully aware of possible negative impacts of culture shock related to the challenges of integration into the society of the host country [25, p. 572], which eventually cause inner psychological issues (S. Poyrazli [26]), affecting the educational potential and adaptive capacity of a foreign student in general. Furthermore, students can be provided with counselling services via video conferencing. The TAO Therapy provides for the participation of students in the following courses:

\section{Cognitive Behavioural for Anxiety.}

Notably, cognitive behavioural therapy focuses on analysing and changing dysfunctional thinking patterns, which can eventually result in positive transformations in a student's behaviour and emotional state. An example of an issue existing in the members of this group is anxiety accompanied by an exaggeration of the level of danger the individual is exposed to, as well as the insufficiency of the potential resources available for dealing with adverse circumstances. The group's activities are divided into the following modules: understanding what anxiety and worry are, easing concerns, thoughts and beliefs, attentiveness, facing one's inner fears, studying the nature of anxiety. Thus, the special feature of the TAO Therapy programme is shifting away from generalising issues relevant for international students, which allows focusing on various areas of concern divided into modules.

It is essential to understand that the existence of stressful situations and anxiety are not unique to international students studying at universities and colleges in the US. Stress factors typical for foreign students have been studied by M. Becker, S. Dong \& J. Kronholz [27], N. Khawaja, S. Chan \& G. Stein [28], M. Poulakis, C. Dike \& A. Massa [29]. Psychological services at Ukrainian HEIs should also be considered in the context of the international students' need for counselling, including remote counselling. According to the finding of the study O. Dobrotvor [30, p. 51], there are "three main types of adaptation: physiological, psychological and social", which evidences the necessity of developing remote counselling programmes at educational institutions attended by international students following the example of the TAO Therapy of the Florida International University and with the use of informational and reference resources and allowing students to continue counselling via video conferencing. For this to happen, we believe it is necessary to create a psychological support platform at least at the local, institution-based if not state level.

2. Cognitive Behavioural for Depression.

The negative attitude of an individual towards the environment is a symptom of depression. The course consists of the following modules: the review of the concept of depression, feelings and thoughts, understanding of the nature of stress, healthy and unhealthy thinking, lifestyle and problem solving, setback prevention. The participation of international students in this course allows providing counselling remotely to address the depression-related issues.

3. Acceptance and Commitment for Anxiety / Depression.

If international students cannot effectively interact in the new society, it leads to certain psychological issues and, eventually, to depression [31, p. 902]. Therefore, this course focuses on accepting the existing environment, i.e., if a person is able to get rid of the thoughts about the necessity to overcome and combat their issues through accepting their existence, the symptoms will become a by-product rather than defining. The group's activities are divided into modules such as the review of depression, an introduction to the basics of acceptance and commitment therapy, attentiveness, values, etc. To summarise, the remote TAO Therapy programme covers different counselling courses, from helping to overcome common adaptation issues and 
depression to solving these issues through their acceptance and thus minimising negative symptoms caused by culture shock.

\section{Behavioural Activation for Depression.}

The objective of the course is to overcome depression from the inside. The duration of the impact of depression on a person affects the degree of self-isolation of this student, which eventually worsens depression and its negative impacts, affecting behaviour and emotional state of the individual. Therefore, the task of behavioural activation is to help introduce the individual to the new reality, as well as to the resources for inner well-being. Such activity results in the formation of hopes and life goals and helps to improve mood and motivation. Group sessions are divided into modules, including the following: the review of the nature of depression, behavioural activation, drawing up an activation plan and defining values, issue solving, life balance, etc. Therefore, this course remotely combines "psychological, social and cultural adaptation" [32, p. 1199], thus allowing students to overcome consequences of culture shock through the use of their inner resources (including those that are culturally oriented). Together with the access to video counselling services through the use of modern communication means, an international student receives an adequate level of psychological support even in the context of a remote academic process.

Thus, the TAO Therapy programme is a platform offering courses for the provision of remote support for international students. The key elements of this programme are the following: providing information support, which allows students to acquire theoretical knowledge on the impact of culture shock and issues it may cause, thus first and foremost ensuring the understanding of the nature of the issue to be overcome, as well as facilitating counselling services via video conferencing, which helps to establish the link "counsellor - counselee" or other links in case of group psychological conferences. The experience of this programme can be extrapolated into the environment of higher education institutions through creating a psychological support platform at these institutions (or at the state level), which would facilitate sharing and reviewing theoretical materials and, eventually, holding video sessions, which would not require the direct use of the platform. Therefore, the experience of this programme for counselling can be used when establishing the infrastructure necessary for remote counselling.

\section{Online-workshops at the Florida International University}

Online Workshops and Resources [33]. This programme consists of several units, namely:

1. Anger Management, which, in turn, includes the following seminars:

- Florida Anger Management Class [34] can have various counselling load and consists of four, eight, twelve or sixteen hours of training. The entire course can be completed through electronic communication, so a student does not have to keep in touch with a counsellor by telephone or using other means. The course covers the following units: understanding of the nature of anger, awareness of anger, stages of anger, healthy thinking, attentiveness, positive thinking, effective communication, conflict solving, anger management, etc. These topics include factors helping to weaken the impact of triggers for anger and strengthen the ability of a person to control it. The quality of a programme, unit, or seminar is directly related to the "way the material is handled" [35, p. 1725]. Therefore, it is important that even seminars such as the Florida Anger Management Class, which do not require the direct link "counsellor - counselee", for example, through video conferencing, ensure a clear sequence of theoretical counselling information. That is why the topics covered by seminars start with considering general concepts and explaining the nature of anger in the context of culture shock and ends with focusing on solutions to conflict situations and an ability to control one's emotional state, which is important not only for academic activities of an individual but for their social activities as well. For example, I. Leontyeva [36, p. 1] states that the remote education system (previously, we have already concluded that counselling is a part of the learning process of an international student as an element of the acculturation triad) should, among other things, take into account "social factors", and the ability to control one's emotional state (a part of which is anger) can be described as an ability of a person to interact with other members of society.

Consequently, the availability of a platform for remote counselling is not evidence of the effectiveness of the process of supporting an international student. The quality of the service can be improved through a properly developed counselling strategy.

- The Logan Group Anger Management Classes [37]. Participation in this seminar includes obtaining a certificate of completion of the course on controlling one's emotional state. Students can join these groups upon the recommendation of their educational institutions to complete a course on anger management. Therefore, participation in this remote seminar is aimed at a more specific objective. Firstly, a participant obtains a document confirming their emotional control skills (which is important for a student as for a future professional), and secondly, students are sent to this seminar by their educational institutions, which means that their inability to effectively control their negative emotions has already affected their academic progress. However, the active involvement of a counsellor, especially through faceto-face interaction, is primarily needed in case of counselling students with an evident lack of emotional self-control. Therefore, we believe that the Anger Management initiative is useful for reviewing and extrapolating its experience into the environment of Ukrainian HEIs in the context of establishing a clear sequence of the provision of theoretical and psychological information for international students.

\section{Time Management [33].}

The negative effects of culture shock include not only "acculturation stress, anxiety and depression" [38, p. 955]. The reason for a person's inability to guide their emotional 
state in the direction necessary for effective academic and social processes is also the absence or insufficiency of self-management skills, which prevents managing their academic time according to their daily schedule, which also results in negative emotional responses such as anger. For example, according to G. Homych \& R. Tkach [39, p. 25], "one of the basic tenets of therapy is that a patient has to learn to control their life", which is impossible without self-management.

In this regard, international students undergoing the remote Time Management course at the Florida International
University are offered to analyse the effectiveness of the use of time within their daily schedule using a special questionnaire (Fig. 2). Its results help both discover self-managing issues and identify an activity that can be excluded or reduced in duration without negative consequences for an individual. The questionnaire can be filled out online, and then the results can also be analysed by the students without or with the help of a counsellor (in our opinion, the latter option is preferable), especially when an interaction between the student and the professional is conducted via video conferencing rather than by correspondence.

\section{Time Management Checklist \\ Rowena Ramnath-Fernandes, Psy.D. \\ Florida International University \\ Counseling \& Psychological Services Center}

Print this page, check off the activities that apply to you and write in the number hours spent on each activity per day. Please leave blank any activity that does not apply to you. Once completed, tabulate the number of hours. If you days vary, think of your most average day and then fill in the hours. At the end of the checklist, total the number of hours you have listed. See below for analysis

$\checkmark$ Activity

- Meals (breakfast, lunch, dinner, other)

- Shower

— Getting dressed/make up/hair

- Driving to/from work

— Driving to/from class

- Attending work

— Attending Class

— Talking on the phone and/or texting

— Using the Internet (includes emails, IMs, chatrooms)

— Spending time with friends (includes going out/clubbing)

— Spending time with family

- Watching TV

— Reading magazines/newspapers/leisure books

— Work preparation

— Studying

- Exercise

- Sleeping (includes naps)

_ Other activities not listed

Total Hours per Day 
of informational reference materials and a further opportunity to interact with a counsellor via video conferencing. However, the Florida International University divides the TAO Therapy programme into four courses, namely "Cognitive Behavioral for Anxiety", "Cognitive Behavioral for Depression", "Acceptance and Commitment for Anxiety/ Depression", "Behavioral Activation for Depression", and each of them provides for the participation of a specific group of international students with certain counselling needs. In conclusion, the use of modern remote communication means allows addressing issues in the context, from changing dysfunctional thinking and negative attitude towards the environment expressed through the symptoms of depression, to accepting existing aspects of the environment and strengthening the student's focus on life goals and finding inner prerequisites for overcoming the consequences of culture shock.

As for the Online Workshops and Resources programme, it provides the opportunity to take part in "Florida Anger Management Class", “The Logan Group Anger Management Classes" seminars (which are aimed at overcoming negative consequences of culture shock caused by depression that can negatively impact both a foreign student and those around them), as well as in the Time Management seminar (which, in our opinion, is among the most important available seminars, because poor time management skills often serve as a catalyst for depressed and aggressive state).

\section{CONCLUSIONS}

The COVID-19 pandemic has become a catalyst for a vigorous development of remote platforms that provide students with necessary materials and allow their introduction into the education process. Since the adaptation of international students is a part of the education system, there is a need for working with such persons not only in the context of linguistic, social and cultural preparation, but factoring in the psychological aspect as well. The United States of America were selected for the study because this country has adequate experience in adaptation of international students. When choosing among the US universities, we selected the University of Minnesota and the Florida International University and analysed their remote counselling systems.

The research demonstrated that the remote system of counselling of international students used at the Florida International University is more structured (in comparison with the system of the University of Minnesota), provides a more extensive range of psychological support services and allows efficiently establishing the link "counsellor - counselee". We believe the practices used at this educational institution can be extrapolated into the remote educational space of other HEIs with international students. There are the following prerequisites:

1. Awareness on the part of the Ministry of Education and the administration of a HEI of the need for the provision of psychological support for international students, in particular in the context of quarantine restrictions.

2. Availability of an appropriate platform for counselling that can be used in a separate format or be a part of an already existing educational platform (to share informational reference material in the form of text and video content).

3. The ability of a counsellor to hold sessions in the format of video conferences to discuss informational reference material and issues that are relevant for a foreign student.

Therefore, further research in this area can address the integration of remote counselling practices into activities of education-related psychological services, analyse the practices of other countries (other than the US) in the use of online counselling courses, etc.

\section{REFERENCES}

[1] Ukrainian State Center of International Education, Ukraine's income from foreign students over the period of their studies is more than 3 billion US dollars. (2021). Retrieved from https://mon.gov.ua/ua/news/dohid-ukrayini-vidinozemnih-studentiv-za-period-yih-navchannya-stanovit-ponad-3-milyardi-dolariv-ssha-ukrayinskij-derzhavnijcentr-mizhnarodnoyi-osviti.

[2] Tsymbaliuk, I.M. (2005). Psychological counseling and correction. Kyiv: VD Profesional.

[3] Widodo, H., Ferdiansyah, S., \& Fridani, L. (2020). Introduction to international students and COVID-19. Journal of International Students, 10(S3), 1-12.

[4] Hua, J., Zhang, G., Coco, Ch., Zhao, T., \& Hou, N. (2020). Proactive personality and cross-cultural adjustment: The mediating role of adjustment self-efficacy. Journal of International Students, 10(4), 817-835.

[5] Ward, C., Bochner, S., \& Furnham, A. (2001). The psychology of culture shock. East Sussex, UK: Routledge.

[6] Busel, V.T. (Ed.). (2005). Big explanatory dictionary of the modern Ukrainian language. Kyiv, Irpin: VTF "Perun".

[7] Bilodid, I.K., Buryachok, A.A., \& Dotsenko, P.P. (1973). Ukrainian language dictionary. Kyiv: Naukova dumka.

[8] Pichi, V.M. (Ed.). (2013). All about social work: Educational and encyclopedic dictionary. Lviv: "Novyj svit - 2000".

[9] Dovgodko, T. (2013). Adaptation of foreign students to the educational environment of Ukraine. Pedagogic and Psychology of Professional Education, 2, 114-120.

[10] Afanasieva, N.Ye. (2013). Models and methods of Internet-counseling of the specialists in extreme activities. Problems of Extreme and Crisis Psychology, 13, 13-21.

[11] Mytsko, V.M. (2011). Speciality of distance psychological counseling in Internet. Scientific Bulletin of Lviv State University of Internal Affairs (Psychological Series), 1, 68-80. 
[12] Akymenko, Yu.F. (2013). Distance psychological counseling: The answer of modern information technologies to today's requirements. Social Work Problems, 2(3), 42-45.

[13] Postek, S., Ledzińska, M., \& Czarkowski, J. (2010). Psychological and pedagogical problems of distance education for adults. Problems of Education in the $21^{\text {st }}$ Century, 22, 99-108.

[14] Baturau, M. (2015). An overview of the world of MOOCs. Procedia - Social and Behavioral Sciences, 174, 427-433.

[15] Pouezevara, S., \& Horn, L. (2016). MOOCs and online education: Exploring the potential for international educational development. Research Triangle Park, North Carolina: RTI Press.

[16] Kentnor, H. (2015). Distance education and the evolution of online learning in the United States. Curriculum and Teaching Dialogue, 17(1/2), 21-34.

[17] Bakia, M., Shear, L., Toyama, Y., \& Lasseter, A. (2012). Understanding the implications of online learning for educational productivity. Washington: U.S. Department of Education.

[18] Seaman, J.E., Allen, I.E., \& Seaman, J. (2018). Grade increase: Tracking distance education in the United States. London: Pearson.

[19] Hunt, J., \& Eisenberg, D. (2010). Mental health problems and help-seeking behavior among college students. Journal of Adolescent Health, 46(1), 3-10.

[20] Forbes-Mewett, H., \& Sawyer, A.-M. (2016). International students and mental health. Journal of International Students, 6(3), 661-677.

[21] University of Minnesota. Online counseling. Student counseling services. (2020). Retrieved from https://counseling. umn.edu/counseling/online.

[22] Florida International University. Online self-help. Counseling \& Psychological Services. (2020). Retrieved from https://studentaffairs.fiu.edu/health-and-fitness/counseling-and-psychological-services/caps-online/index.php.

[23] TAO-FIU explainer video. Therapy assistance online. (2020). Retrieved from https://vimeo.com/187248053.

[24] Florida International University. Therapy assistance online (TAO). Counseling \& Psychological Services. (2020). Retrieved from https://studentaffairs.fiu.edu/health-and-fitness/counseling-and-psychological-services/caps-online/ caps-self-help-services/index.php.

[25] Chai, D., Van, H., Wang, C.-W., Lee, J., \& Wang, J. (2020). What do international students need? The role of family and community supports for adjustment, engagement, and organizational citizenship behavior. Journal of International Students, 10(3), 571-589.

[26] Poyrazli, S., \& Mitchell, M. (2020). Mental health problems of U.S. students studying abroad. Journal of International Students, 10(1), 17-27.

[27] Becker, M., Dong, S., Kronholz, J., \& Brownson, C. (2018). Relationships between stress and psychosocial factors with sources of help-seeking among international students. Journal of International Students, 8(4), 1636-1661.

[28] Khawaja, N., Chan, S., \& Stein, G. (2017). The relationship between second language anxiety and international nursing students stress. Journal of International Students, 7(3), 601-620.

[29] Poulakis, M., Dike, C., \& Massa, A. (2017). Acculturative stress and adjustment experiences of Greek international students. Journal of International Students, 7(2), 204-228.

[30] Dobrotvor, O.V., \& Shherbyna, I.Yu. (2017). Adaptation of foreign students in the educational process of Ukrainian university. Proceedings of the National Aviation University, 10, 51-54.

[31] Aldawsari, N.F., Adams, K.S., Grimes, L.E., \& Kohn, S. (2018). The effects of cross-cultural competence and social support on international students' psychological adjustment: Autonomy and environmental mastery. Journal of International Students, 8(2), 901-924.

[32] Bastien, G., Seifen-Adkins, T., \& Johnson, L. (2018). Striving for success: Academic adjustment of international students in the U.S. Journal of International Students, 8(2), 1198-1219.

[33] Florida International University. Online workshops and resources. Counseling \& Psychological Services. (2020). Retrieved from https://studentaffairs.fiu.edu/health-and-fitness/counseling-and-psychological-services/caps-online/ online-resources/index.php.

[34] About the online anger management class. Course for anger. Anger management class. (2020). Retrieved from https://courseforanger.com/about-the-course.

[35] Karkar-Esperat, T.M. (2018). International graduate students' challenges and learning experiences in online classes. Journal of International Students, 8(4), 1722-1735.

[36] Leontyeva, I.A. (2018). Modern distance learning technologies in higher education: Introduction problems. EURASIA Journal of Mathematics, Science and Technology Education, 14(10), article number 1578.

[37] Anger management classes. The Logan Group Int. (2020). Retrieved from http://www.successwithlogan.com.

[38] Luo, Z., Wu, S., Fang, X., \& Brunsting, N. (2019). International students' perceived language competence, domestic student support, and psychological well-being at a U.S. University. Journal of International Students, 9(4), 954-971.

[39] Homych, H.O., \& Tkach, R.M. (2004). Fundamentals of psychology counseling. Kyiv: MAUP. 


\section{Ярослав Сергійович Слуцький', Колін Бланшард²}

${ }^{1}$ Донбаський державний коледж технологій та управління 85200, вул. Євгена Седнєва, 3А, м. Торецьк, Україна

${ }^{2}$ Університет штату Індіана

IN 47809, вул. Сьома Північна, 200, м. Терре-Хот, Сполучені Штати Америки

\section{Програми дистанційного психологічного консультування іноземних студентів у системі вищої освіти Сполучених Штатів Америки}

Анотація. Актуальність дослідження полягає в необхідності розвитку дистанційних форм консультаційної роботи з іноземними студентами під час адаптаційного періоду. У зв'язку з цим метою наукового дослідження $є$ аналіз програм дистанційного психологічного консультування іноземних студентів у ЗВО США для виявлення перспектив екстраполяції зарубіжного досвіду в систему вищої освіти інших держав. У процесі дослідження був застосований комплекс методів: аналіз, синтез, абстрагування, перехід від абстрактного до конкретного, що дав змогу провести всебічне вивчення проблеми дистанційного психологічного консультування іноземних студентів. У статті досліджено особливості психологічного онлайн-консультування іноземних студентів. Відзначено, що психологічна підтримка є елементом акультураційної тріади, тому має розглядатися в межах освітнього процесу. Підкреслено, що іноземні студенти схильні до негативного впливу феномену «культурного шоку», тому необхідна їхня участь у відповідних заходах, спрямованих на розвиток навичок подолання емоційних і психологічних проблем. Проаналізовано програми, курси та семінари University of Minnesota та Florida International University, що дало змогу виявити наявність певного алгоритму вибудовування дистанційної системи психологічного консультування, а саме: надання іноземним студентам теоретико-інформаційного матеріалу (що складається 3 текстових і відеоматеріалів) для особистісного ознайомлення й формування спільного розуміння сутності проблем, актуальних для представників інших країн; проведення безпосереднього контакту студента 3 консультантом за допомогою відеозв'язку, що дає змогу обговорити наявні проблеми психологічного характеру та вибудувати міжособистісні взаємозв'язки. Практична цінність дослідження полягає в тому, що розвиток дистанційних програм, курсів, семінарів (з упровадженням зарубіжного досвіду ведення такої діяльності) буде мати позитивний вплив на загальнодержавну систему психологічної підтримки та надасть можливість більш активного використання сучасних ІКТ не тільки в освітній сфері

Ключові слова: культурний шок, негативна психологічна акультураційна система, теоретико-інформаційний матеріал, платформа психологічної підтримки 